\title{
Ketahanan Beberapa Genotipe Jagung Hibrida Umur Genjah terhadap Sitophilus zeamais Motschulsky
}

\section{Resistance of Several Early Maturing Hybrid Maize Genotypes to Sitophilus zeamais Motschulsky}

\author{
Suriani*, Andi Tenrirawe, dan Andi Takdir Makkulawu \\ Balai Penelitian Tanaman Serealia \\ Jl. Dr. Ratulangi No. 274 Maros 90514, Sulawesi Selatan, Indonesia
}

Diterima 25 April 2018/Disetujui 19 Februari 2019

\begin{abstract}
Sitophilus zeamais is a major pest of cereal products in the storage that can reduce the quality and quantity of the grain. The use of resistant variety is an efficient method to control $\underline{S}$. zeamais. This research aimed to evaluate the resistance of 8 early maturing hybrid maize genotypes to $\underline{S}$. zeamais. The research was arranged in a single factor completely randomized design with 3 replications, involving 8 genotypes and 4 check varieties. Samples of $25 \mathrm{~g}$ seeds were stored in the container covered by gauze, then infested with same-aged 5 males and 5 females of $\underline{S}$. zeamais and maintened to 105 days. Observed variables were the number of F1 progenies of $\underline{S}$. zeamays, susceptibility index, seed damage, and weight loss. Based on the results, 3 early maturing hybrid maize genotypes (CH-19, $\mathrm{CH}-18$ and $\mathrm{CH}-20)$ exhibited high resistance to the $\underline{\mathrm{S}}$. zeamais as indicated by their susceptibility index, number of progenies, percentage of seed damage, and weight loss. These genotypes had susceptibility index of 1.23-1.80 with low percentage of seed damage of 2.07-4.55\%. Correlation tests showed that the susceptibility index of maize seeds had positive correlation with number of progenies and seed damage.
\end{abstract}

Keywords: seed, stored pest, susceptibility index

\section{ABSTRAK}

Sitophilus zeamais merupakan hama utama produk serealia di penyimpanan yang dapat menurunkan kualitas dan kuantitas biji. Penggunaan varietas tahan merupakan metode pengendalian $\underline{\text { S. zeamais } y a n g ~ e f i s i e n . ~ P e n e l i t i a n ~ i n i ~ b e r t u j u a n ~}$ menguji ketahanan 8 genotipe jagung hibrida umur genjah terhadap $\underline{S}$. zeamais. Pengujian disusun berdasarkan rancangan acak lengkap faktor tunggal dengan 3 ulangan, melibatkan 8 genotipe dan 4 varietas pembanding. Contoh benih berukuran $25 \mathrm{~g}$ disimpan di dalam wadah yang ditutup kain kasa, kemudian diinfestasikan dengan $\underline{\text { S. zeamais }}$ (5 ekor jantan dan 5 ekor betina, berumur seragam) dan dipelihara hingga 105 hari. Variabel pengamatan meliputi jumlah keturunan baru (F1) $\underline{S}$. zeamais, indeks kerentanan, kerusakan biji, dan susut bobot biji. Berdasarkan hasil pengujian didapatkan 3 genotipe jagung

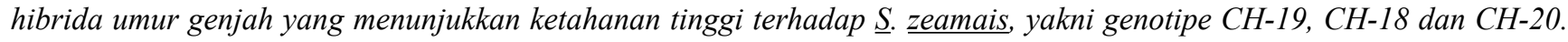
Ketahanan tersebut terlihat pada indeks kerentanan, jumlah keturunan baru (F1) $\underline{S}$. zeamais, persentase kerusakan biji dan susut bobot biji. Indeks ketahanan ketiganya berkisar 1.23-1.80 dengan persentase kerusakan biji sangat rendah yakni 2.07-4.55\%. Uji korelasi menunjukkan bahwa indeks kerentanan biji jagung terhadap $\underline{\text { S. zeamais }}$ berkorelasi positif dengan jumlah keturunan baru yang dihasilkan dan kerusakan biji.

Kata kunci: biji, hama gudang, indeks kerentanan

\section{PENDAHULUAN}

Sitophilus zeamais Motschulsky merupakan salah satu hama penting yang menyerang tanaman serealia terutama selama penyimpanan (Nonci dan Muis, 2015; Suleiman, 2015). Beberapa tahun terakhir ini, pengujian ketahanan calon varietas jagung terhadap $S$. zeamais tidak menjadi

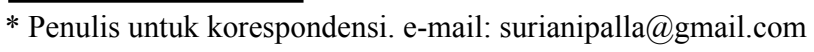

prasyarat dalam pelepasan varietas jagung. Namun data di lapangan memperlihatkan kehilangan hasil akibat serangan S. zeamais di Indonesia dilaporkan mencapai 30\% (Tenrirawe et al., 2013). Berdasarkan hal tersebut, pengujian terhadap galur, populasi atau varietas jagung terhadap $S$. zeamais perlu terus dilakukan untuk mengurangi penurunan kuantitas dan kualitas biji.

Penurunan kuantitas dan kualitas biji jagung disebabkan karena adanya lubang bekas gerekan $S$. zeamais pada biji. Hal ini dikarenakan imago menggerek 
biji kemudian meletakkan telur satu per satu pada lubang gerekan. Seluruh fase perkembangan hama ini mulai dari telur sampai imago berada dalam biji, sebelum keluar dari biji imago membuat lubang keluar pada pericarp sehingga biji menjadi berlubang lebih besar (Hasnah et al., 2014). Penyimpanan secara tradisional tanpa pengelolaan pasca panen yang tepat memicu peningkatan populasi $S$. zeamais dan mengakibatkan susut bobot biji hingga 80\% (Tefera et al., 2011). Benih jagung yang terserang S. zeamais memiliki daya kecambah menurun. Lebih lanjut dikemukakan Cosmas et al. (2012) bahwa biji jagung yang diinfestasikan $S$. zeamais dan disimpan selama 56 hari mengalami penurunan bobot biji sebesar $80-100 \%$.

Dampak lain dari serangan S. zeamais yakni bekas gerekan pada biji dapat ditumbuhi cendawan Fusarium spp. dan Aspergillus spp. Kedua cendawan tersebut berbahaya jika dikomsumsi manusia ataupun ternak karena adanya senyawa racun berupa fumonisin yang diproduksi oleh Fusarium spp. dan aflatoksin yang diproduksi oleh Aspergillus spp. (Pakki, 2016). Fumonisin dilaporkan oleh Nayaka et al. (2009) sebagai salah satu penyebab tingginya kasus kanker esophagus pada manusia di Afrika bagian selatan.

Teknik pengendalian $S$. zeamais yang tepat dan mudah dilakukan ialah penggunaan varietas tahan (Herlina dan Istiaji, 2013). Beberapa varietas jagung yang tahan terhadap hama yang sudah sampai dimasyarakat di antaranya varietas Srikandi Kuning, Sukmaraga, dan Bisi 2; namun ketiga varietas memiliki umur tanam yang lebih panjang 97-110 hari (Surtikanti, 2004; Mas'ud et al., 2009; Aqil dan Arvan, 2016). Perakitan varietas tahan melalui program pemuliaan dimulai dengan mengumpulkan berbagai plasma nutfah kemudian melakukan penapisan. Identifikasi ketahanan genotipe tanaman koleksi merupakan langkah awal dalam pengembangan kultivar tahan (Zainal et al., 2011). Upaya perakitan varietas unggul tahan $S$. zeamais, produksi tinggi, dan umur tanam lebih pendek harus dikembangkan lebih lanjut dalam kegiatan pemuliaan.

Penelitian perakitan varietas jagung hibrida umur genjah yang telah dilakukan dan menghasilkan 8 genotipe jagung hibrida umur genjah yang terbaik di antara genotipe uji lainnya berdasarkan aspek produksi dan umur tanam yang lebih pendek. Kedelapan genotipe tersebut ialah $\mathrm{CH}$ 17, $\mathrm{CH}-18, \mathrm{CH}-19, \mathrm{CH}-20, \mathrm{CH}-22, \mathrm{CH}-23, \mathrm{CH}-24$, dan $\mathrm{CH}-27$. Perakitan varietas jagung hibrida umur genjah diperuntukkan untuk peningkatan produksi tanaman jagung pada lahan yang mengalami cekaman kekeringan dan lahan tadah hujan (Suriani et al., 2016). Selain dua karakter unggul tersebut yang diharapkan dari perakitan jagung hibrida umur genjah, ketahanan genotipe terhadap $S$. zeamais perlu dipertimbangkan untuk menjaga kuantitas dan kualitas biji selama penyimpanan.

Berdasarkan hal tersebut, maka penelitian ini dilakukan untuk menguji ketahanan beberapa genotipe jagung hibrida umur genjah terhadap serangan $S$. zeamais. Genotipe yang tahan dari hasil penelitian ini akan dijadikan bahan kegiatan pemuliaan untuk perakitan varietas jagung hibrida umur genjah yang tahan terhadap $S$. zeamais.

\section{BAHAN DAN METODE}

Penelitian dilakukan pada September 2016 hingga Januari 2017 di Laboratorium Hama Balai Penelitian Tanaman Serealia dengan menggunakan 8 genotipe jagung yang merupakan calon varietas jagung hibrida umur genjah yaitu genotipe $\mathrm{CH}-17, \mathrm{CH}-18, \mathrm{CH}-19, \mathrm{CH}-20, \mathrm{CH}-22, \mathrm{CH}-$ 23, $\mathrm{CH}-24, \mathrm{CH}-27$ dan 4 varietas pembanding yaitu $\mathrm{HJ}-21$, NK 212, BISI 2, dan Bima 14. Penelitian disusun dalam rancangan acak lengkap (RAL) dengan tiga ulangan.

\section{Perbanyakan S. zeamais}

Perbanyakan $S$. zeamais dilakukan dengan cara memasukkan S. zeamais dengan populasi kurang lebih 200 ekor imago ke dalam wadah plastik yang berisi biji jagung varietas Anoman selama satu minggu untuk meletakkan telur. Selanjutnya serangga tersebut dikeluarkan dengan harapan akan keluar serangga baru yang berumur seragam. Setelah penyimpanan selama 45 hari, dihasilkan serangga baru yang berumur seragam untuk selanjutnya digunakan dalam penelitian.

\section{Pengujian Ketahanan Genotipe-genotipe Jagung}

Biji jagung yang akan diuji terlebih dahulu disimpan di dalam freezer selama 2 minggu yang bertujuan untuk mematikan hama gudang dari lapangan. Setiap genotipe ditimbang $25 \mathrm{~g}$ dan dimasukkan ke dalam wadah plastik dengan diameter $7.5 \mathrm{~cm}$ dan tinggi $5 \mathrm{~cm}$. Tutup wadah plastik dilubangi dan diganti dengan kain kasa dengan tujuan sirkulasi udara dalam wadah tetap berlangsung. Selanjutnya diinvestasikan $S$. zeamais yang berumur 35 hari masingmasing 5 ekor jantan dan 5 ekor betina yang diidentifikasi jenis kelamin berdasarkan karakteristik rostrumnya (Tenrirawe, 2004). Imago dikeluarkan dari wadah setelah 15 hari dan biji jagung tetap disimpan pada kondisi yang sama hingga keturunan baru (F1) keluar.

\section{Jumlah Keturunan Baru (F1)}

Pengamatan dimulai pada saat imago S. zeamais keluar pertama kali dari biji dan pengamatan berikutnya dilakukan setiap hari hingga 107 hari setelah investasi imago $S$. zeamais. Jumlah serangga yang keluar setiap hari dihitung secara kumulatif sehingga diperoleh data jumlah keturunan baru (F1). Upaya untuk mencegah terjadinya infestasi generasi kedua yaitu semua imago yang muncul pada saat pengamatan dikeluarkan dari wadah.

\section{Indeks Kerentanan}

Nilai indeks kerentanan diperoleh dengan mengetahui jumlah keturunan baru (F1) dan menghitung waktu perkembangan serangga pada setiap genotipe. Dihitung dengan indeks Dobie (1974), yaitu dengan persamaan:

$$
\mathrm{SI}=\frac{\mathrm{Ln} \mathrm{F}}{\mathrm{DME}}
$$


Keterangan:

SI $=$ Indeks kerentanan

Ln = Logaritma biasa

$\mathrm{F} \quad=$ Jumlah total keturunan baru (F1)

$\mathrm{DME}=$ Waktu perkembangan $\mathrm{F} 1$

Nilai skoring indeks kerentanan biji jagung terhadap S. zeamais yaitu: nilai indeks kerentanan 0-3 dikategorikan tahan; nilai indeks kerentanan 4-7 dikategorikan cukup tahan; nilai indeks kerentanan 8-10 dikategorikan rentan; nilai indeks kerentanan $>11$ dikategorikan sangat rentan.

\section{Kerusakan Biji (\%)}

Jumlah biji rusak (biji yang berlubang) dihitung setelah seluruh imago $S$. zeamais muncul dari setiap perlakuan. Kerusakan biji dinyatakan sebagai proporsi dari total sampel biji (Abebe et al., 2009).

\section{Persentase Susut Bobot Biji (\%)}

Persentase susut bobot biji menggunakan rumus sebagai berikut (Gwinner et al., 1996):

$$
P=\frac{(\mathrm{WU} \times \mathrm{Nd})-(\mathrm{WD} \times \mathrm{Nu})}{\mathrm{WU}(\mathrm{Nd}+\mathrm{Nu})}
$$

Keterangan:

$$
\begin{array}{ll}
\mathrm{P} & =\text { Persentase susut bobot biji (\%) } \\
\mathrm{WU} & =\text { Berat biji utuh } \\
\mathrm{Nu} & =\text { Jumlah biji utuh } \\
\mathrm{WD} & =\text { Berat biji rusak } \\
\mathrm{Nd} & =\text { Jumlah biji rusak }
\end{array}
$$

Data hasil pengamatan dianalisis dengan sidik ragam. Jika perlakuan berpengaruh nyata, dilakukan uji lanjut Duncan Multiple Range Test pada taraf $\alpha=5 \%$. Hubungan antar variabel pengamatan diketahui dengan uji korelasi sederhana Pearson pada tingkat kepercayaan 95\%. Adapun kekuatan hubungan antara variabel adalah sangat lemah jika nilai $r=0.00-0.199$, lemah jika nilai $r=0.20-0.399$, cukup kuat jika nilai $r=0.40-0.599$, kuat jika nilai $r=0.60-0.799$, sangat kuat jika nilai $\mathrm{r}=0.80-1.00$. Jika korelasinya negatif, interpretasinya serupa (Siregar, 2013).

\section{HASIL DAN PEMBAHASAN}

\section{Jumlah Keturunan Baru (F1)}

Keturunan baru (F1) pertama kali ditemukan keluar dari biji pada saat 41 hari setelah investasi imago $S$. zeamais. Jumlah populasi keturunan baru (F1) S. zeamais yang ditemukan bervariasi dengan kisaran antara 6-72 ekor (Tabel 1). Jumlah F1 terbanyak ditemukan pada varietas Bima 14 sebanyak 72 ekor. Sementara jumlah F1 pada 9 genotipe uji lebih sedikit dibandingkan dengan Bima 14, bahkan pada genotipe $\mathrm{CH}-19$ hanya terdapat 6 ekor.

Genotipe jagung dengan jumlah turunan F1 yang sedikit diduga memproduksi senyawa yang dapat menghambat perkembangan dan peletakan telur $S$. zeamais seperti senyawa fenolik (Tenrirawe dan Tandiabang, 2009). Senyawa fenolik dalam jumlah tinggi dapat membatasi imago S. zeamais dalam peletakan telur. Diketahui bahwa jumlah turunan pertama $S$. zeamais erat kaitannya dengan perilaku oviposisi dari induk betina. Faktor lingkungan pada penelitian ini tidak menjadi pembatas perkembangan serangga karena pelaksanaan penelitian di laboratorium dalam kondisi yang terkontrol.

\section{Indeks Kerentanan Biji terhadap Serangan $\underline{S}$. zeamais}

Indeks kerentanan terhadap serangan $S$. zeamais berbeda secara signifikan antar genotipe (Tabel 2). Semua genotipe uji menunjukkan sifat tahan terhadap $S$. zeamais, beda halnya dengan varietas Bima 14 yang bersifat agak tahan terhadap serangan $S$. zeamais.

Delapan genotipe uji menunjukkan sifat tahan terhadap S. zeamais dengan indeks kerentanan di bawah 3 , indeks ketahanan terendah terdapat pada genotipe $\mathrm{CH}-18, \mathrm{CH}-19$, dan $\mathrm{CH}-20$ yang masing-masing sebesar 1.74, 1.23, dan 1.80. Ketiga genotipe ini memiliki indeks ketahanan yang berbeda secara signifikan dengan varietas Bima 14. Indeks ketahanan biji jagung terhadap $S$. zeamais dipengaruhi oleh banyaknya jumlah keturunan baru yang muncul dan lama waktu perkembangan serangga. Genotipe jagung yang rentan memiliki daya tarik terhadap serangga untuk meletakkan telur dan berkembangbiak. Sementara genotipe tahan kemungkinan memproduksi senyawa yang bersifat antibiosis dan non-preferensi sebagai mekanisme resistensi (Keba dan Sori, 2013). Peneliti yang sama menemukan bahwa pada genotipe jagung yang rentan, S. zeamais memiliki siklus hidup lebih pendek berkisar 35.33 hari, pada genotipe tahan siklus hidup akan diselesaikan dalam waktu yang lebih lama.

Tabel 1. Rata-rata keturunan baru (F1) S. zeamais pada setiap genotipe uji

\begin{tabular}{lc}
\hline Genotipe/Varietas & Jumlah keturunan baru (F1) \\
\hline CH-17 & $22 \mathrm{c}$ \\
$\mathrm{CH}-18$ & $9 \mathrm{c}$ \\
$\mathrm{CH}-19$ & $6 \mathrm{c}$ \\
$\mathrm{CH}-20$ & $8 \mathrm{c}$ \\
$\mathrm{CH}-22$ & $33 \mathrm{bc}$ \\
$\mathrm{CH}-23$ & $20 \mathrm{c}$ \\
$\mathrm{CH}-24$ & $29 \mathrm{bc}$ \\
$\mathrm{CH}-27$ & $19 \mathrm{c}$ \\
$\mathrm{NK} 212$ & $19 \mathrm{c}$ \\
$\mathrm{HJ}-21$ & $25 \mathrm{c}$ \\
BISI 2 & $16 \mathrm{c}$ \\
Bima 14 & $72 \mathrm{a}$ \\
\hline
\end{tabular}

Keterangan: Angka-angka yang diikuti oleh huruf yang berbeda berarti menunjukkan perbedaan nyata pada uji DMRT taraf $\alpha=5 \%$ 
Tabel 2. Indeks kerentanan beberapa genotipe jagung hibrida genjah terhadap $S$. zeamais

\begin{tabular}{lccc}
\hline No & $\begin{array}{c}\text { Genotipe/ } \\
\text { varietas }\end{array}$ & $\begin{array}{c}\text { Indeks } \\
\text { kerentanan }\end{array}$ & $\begin{array}{c}\text { Tingkat } \\
\text { kerentanan }\end{array}$ \\
\hline 1 & CH-17 & $3.18 \mathrm{ab}$ & Tahan \\
2 & CH-18 & $1.74 \mathrm{~b}$ & Tahan \\
3 & CH-19 & $1.23 \mathrm{~b}$ & Tahan \\
4 & CH-20 & $1.80 \mathrm{~b}$ & Tahan \\
5 & CH-22 & $3.74 \mathrm{ab}$ & Tahan \\
6 & CH-23 & $2.58 \mathrm{ab}$ & Tahan \\
7 & CH-24 & $3.90 \mathrm{ab}$ & Tahan \\
8 & CH-27 & $2.91 \mathrm{ab}$ & Tahan \\
10 & NK 212 & $2.96 \mathrm{ab}$ & Tahan \\
9 & HJ-21 & $2.86 \mathrm{ab}$ & Tahan \\
11 & BISI 2 & $2.92 \mathrm{ab}$ & Tahan \\
12 & Bima 14 & $5.20 \mathrm{a}$ & Agak tahan \\
\hline
\end{tabular}

Keterangan: Angka-angka yang diikuti oleh huruf yang berbeda berarti menunjukkan perbedaan nyata pada uji DMRT taraf $\alpha=5 \%$

\section{Kerusakan Biji}

Pengamatan terhadap persentase kerusakan biji menunjukkan bahwa genotipe dengan indeks kerentanan yang tinggi yaitu $\mathrm{CH}-22$ memiliki persentase kerusakan biji yang besar pula dan tidak berbeda nyata dengan varietas Bima 14 (Gambar 1). Persentase kerusakan biji terendah ditunjukkan oleh genotipe $\mathrm{CH}-18$ yakni sebesar $2.07 \%$ kemudian disusul genotipe $\mathrm{CH}-19$ dan $\mathrm{CH}-20$ masingmasing $3.67 \%$ dan $4.55 \%$.

Secara keseluruhan, persentase kerusakan biji dari 8 genotipe uji terdapat 6 genotipe dengan persentase kerusakan biji lebih rendah yang secara statistik berbeda nyata dengan varietas Bima 14 yaitu CH-17, CH-18, CH-19, CH-20, $\mathrm{CH}-23$ dan $\mathrm{CH}-27$. Kerusakan biji jagung akibat serangan hama ini diawali dengan adanya lubang gerekan pada biji kemudian lama kelamaan biji menjadi pecah dan hancur (Gambar 2). Kerusakan ini terjadi karena aktivitas makan dari larva dan serangga dewasa (imago) dari S. zeamais. Larva serangga ini berkembang dalam biji jagung sampai menjadi imago. Imago yang baru muncul akan membuat lubang keluar dengan cara menggerek biji dari bagian sehingga membentuk lubang yang lebih besar (Nonci dan Muis, 2015).

Biji jagung yang telah rusak akibat serangan hama ini akan mengalami penurunan daya perkecambahan (Respyan et al., 2015). Bagian bekas gerekan S. zeamais pada biji jagung biasanya ditumbuhi miselia cendawan dan mempengaruhi proses perkecambahan biji sehingga persentase biji berkecambah menjadi menurun. Cendawan yang ditemukan menyerang biji jagung di penyimpanan ada tiga jenis yakni Aspergillus spp., Fusarium spp., dan Penicillium spp (Budiarti et al., 2013; Pakki, 2016; Ahmad, 2009).

\section{Susut Bobot Biji}

Persentase susut bobot biji pada semua genotipe uji dan varietas pembanding tidak menunjukkan perbedaan yang nyata. Genotipe $\mathrm{CH}-22$ yang memiliki indeks kerentanan sebesar 3.74 (Tabel 2), paling tinggi di antara genotipe uji lainnya dan mengalami susut bobot biji yang paling tinggi pula yakni $7.30 \%$ (Gambar 3). Namun hasil uji korelasi menunjukkan bahwa susut bobot biji jagung tidak berkorelasi dengan peningkatan indeks ketahanan biji terhadap S. zeamais (Tabel 3). Hal ini terlihat pada salah satu varietas pembanding yakni Bima 14 memiliki indeks kerentanan 5.20, lebih tinggi dari indeks ketahanan $\mathrm{CH}-22$ namun memiliki persentase susut bobot biji lebih rendah dibandingkan dengan genotipe $\mathrm{CH}-22$.

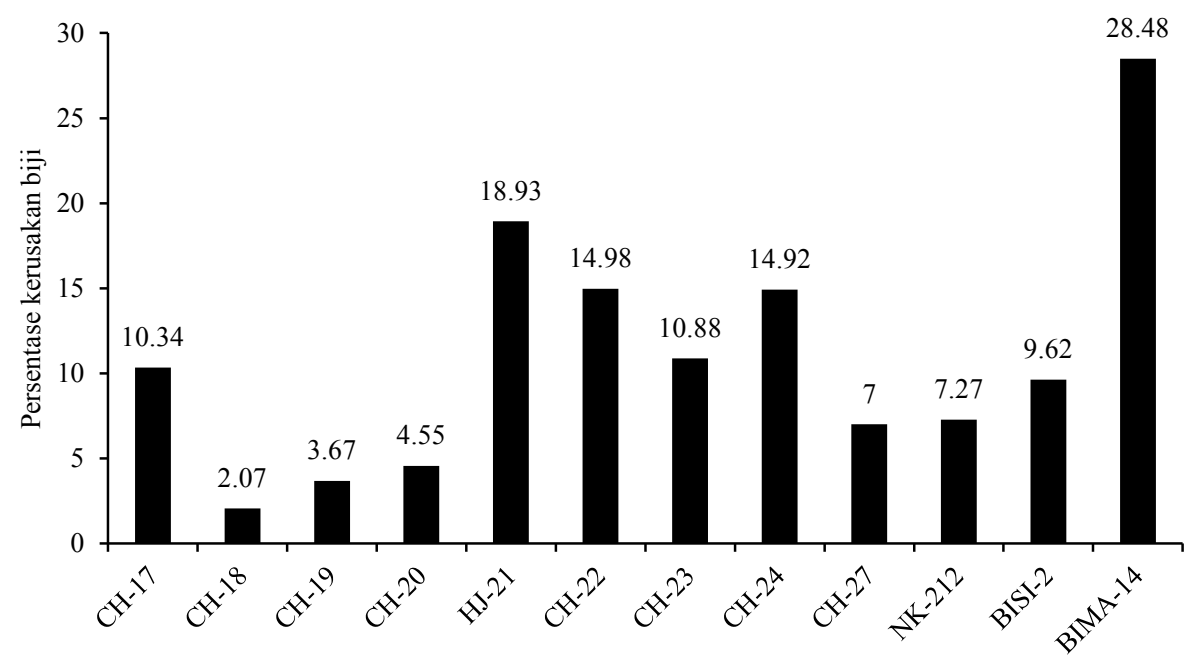

Galur/varietas jagung

Gambar 1. Persentase kerusakan biji jagung pada beberapa genotipe uji akibat serangan S. zeamais 

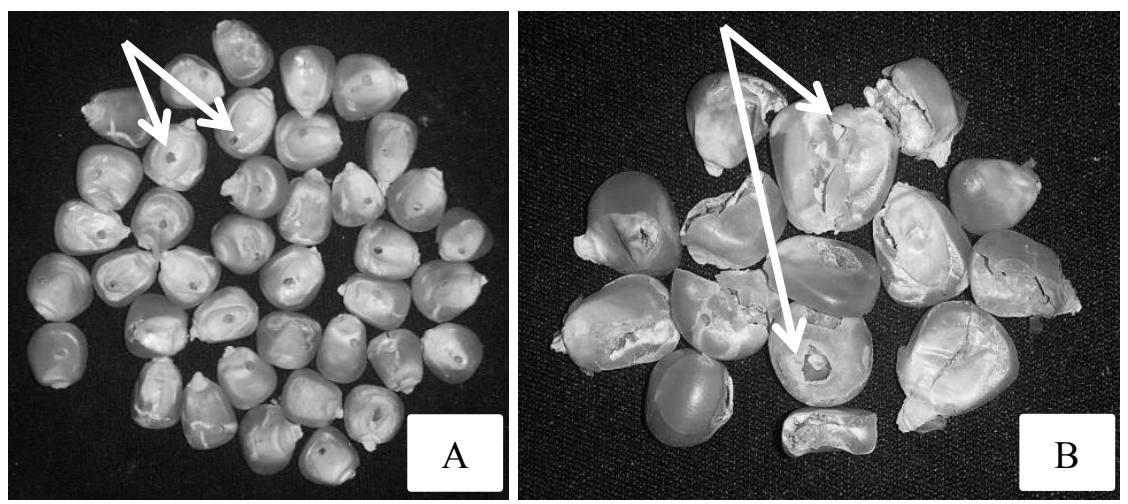

Gambar 2. Gejala kerusakan berupa bekas gerekan S. zeamais pada biji jagung (A) dan biji pecah akibat beberapa gerekan S. zeamais (B)

(B)

Berdasarkan beberapa variabel yang telah diamati, terdapat 3 genotipe uji yang dapat direkomendasikan untuk dikembangkan ialah $\mathrm{CH}-18, \mathrm{CH}-19$ dan CH-20. Ketiga genotipe ini tahan terhadap serangan $S$. zeamais dan memiliki persentase susut bobot biji terendah yakni masingmasing $0.73,1.17$, dan 0.78 .

Informasi tentang tingkat kerentanan genotipe jagung hibrida genjah penting sebagai dasar dalam perakitan varietas jagung. Menurut Hendrival dan Mayasari (2017) ketahanan varietas atau calon varietas jagung terhadap $S$. zeamais memiliki peran penting dalam meminimalkan kerugian selama penyimpanan biji. Penurunan berat biji jagung di penyimpanan dapat mencapai 30-40\% akibat serangan hama ini (Arbogast dan Throne, 1997). Adanya korelasi positif antara kerusakan biji dengan indeks kerentanan dan jumlah keturunan baru $S$. zeamais, maka penggunaan varietas tahan dianjurkan sebagai teknik pengendalian karena dapat memperlambat perkembangan populasi S. zeamais (Nonci dan Muis, 2015).
Korelasi antara Indeks Kerentanan dengan Jumlah F1, Persentase Kerusakan Biji, dan Susut Bobot Biji

Uji korelasi Pearson yang dilakukan menunjukkan bahwa indeks kerentanan suatu genotipe atau varietas jagung berkorelasi positif nyata dengan jumlah keturunan baru dan kerusakan biji dengan nilai korelasi masingmasing 0.92 dan 0.88 . Kedua variabel tersebut memiliki nilai korelasi yang menunjukkan hubungan sangat erat dengan indeks kerentanan biji terhadap S. zeamais. Hal ini berarti semakin tinggi indeks kerentanan biji genotipe atau varietas jagung hibrida genjah maka semakin tinggi pula jumlah F1 S. zeamais dan kerusakan biji. Hubungan yang kuat dan signifikan juga terdapat antara jumlah F1 dengan kerusakan biji, nilai korelasi 0.93. Beberapa penelitian sebelumnya menunjukkan hal yang sama bahwa F1 $S$. zeamais tinggi pada genotipe rentan dan berkorelasi positif dengan persentase kerusakan biji (Abebe et al., 2009; Siwale et al., 2009; Keba dan Sori, 2013). Oleh karena itu, dapat dinyatakan bahwa jumlah keturunan baru berperan penting untuk indeks kerentanan biji jagung terhadap $S$. zeamais.

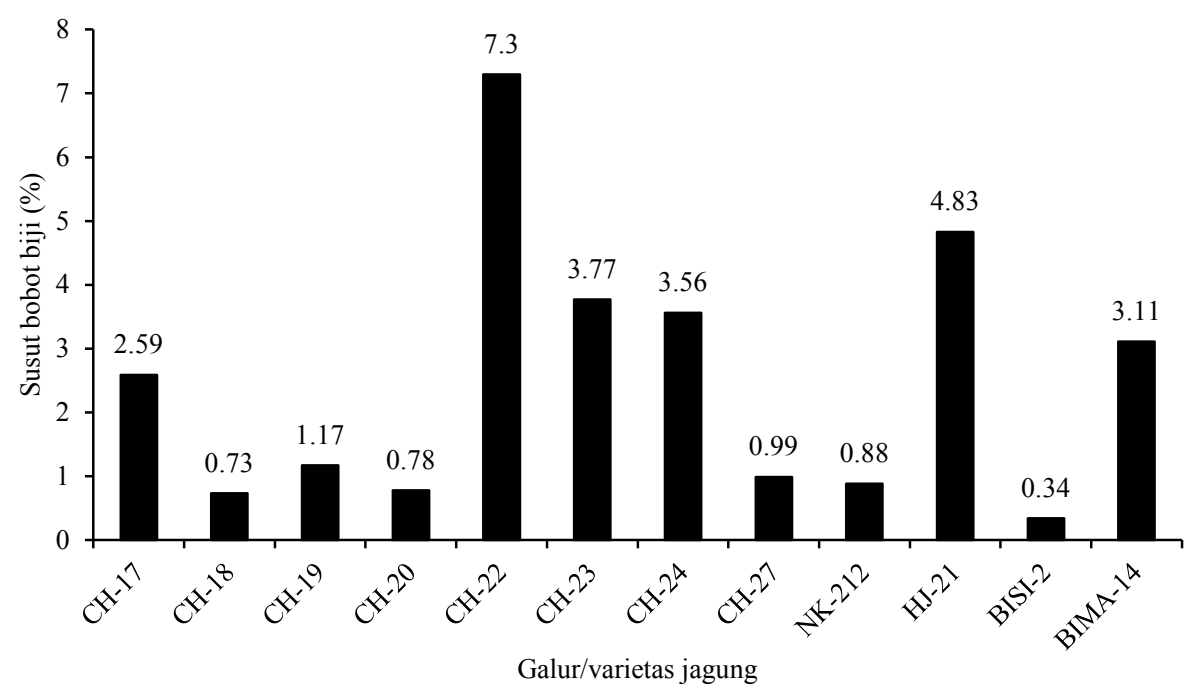

Gambar 3. Persentase susut bobot biji jagung pada beberapa genotipe uji akibat serangan S. zeamais 
Tabel 3. Korelasi antara indeks kerentanan dengan jumlah keturunan baru (F1), persentase kerusakan biji, dan susut bobot biji

\begin{tabular}{lcllc}
\hline & Indeks kerentanan & Jumlah F1 & Kerusakan biji & Susut bobot biji \\
\hline Indeks kerentanan & 1.00 & & & \\
Jumlah F1 & $0.92^{* *}$ & 1.00 & & \\
Kerusakan biji & $0.88^{* *}$ & $0.93^{* *}$ & 1.00 & 1.00 \\
Susut bobot biji & 0.49 & 0.46 & 0.60 & \\
\hline
\end{tabular}

Keterangan: ** nyata pada taraf kesalahan $1 \%$

\section{KESIMPULAN}

Terdapat 3 genotipe jagung hibrida umur genjah yang menunjukkan ketahanan tinggi terhadap $S$. zeamais yaitu genotipe $\mathrm{CH}-19, \mathrm{CH}-18$ dan $\mathrm{CH}-20$, berdasarkan indeks kerentanan, jumlah keturunan baru (F1) S. zeamais, persentase kerusakan biji, dan susut bobot biji. Indeks kerentanan ketiganya berkisar 1.23-1.80 dengan persentase kerusakan biji sangat rendah yakni $2.07-4.55 \%$. Sementara hasil uji korelasi menunjukkan bahwa indeks kerentanan biji jagung terhadap $S$. zeamais berkorelasi positif dengan jumlah keturunan baru yang dihasilkan dan kerusakan biji.

\section{DAFTAR PUSTAKA}

Abebe, F., T. Tefera, S. Mugo, Y. Bayene, S. Vidal. 2009. Resistance of maize varieties to the maize weevil Sitophilus zeamais (Motsch.) (Coleoptera: Curculionidae). Afri J. Biotech. 8:5937-5943.

Ahmad, R.Z. 2009. Cemaran kapang pada pangan dan pengendaliannya. J. Litbang Pertanian 28:15-22.

Arbogast, R.T., J.E. Throne, 1997. Insect infestation of farm-stored maize in South Carolina: towards characterization of a habitat. J. Stored Prod. Res. 33:187-198.

Aqil, M., R.Y. Arvan. 2016. Deksripsi Varietas Unggul Jagung. Balai Penelitian Tanaman Serealia, Maros, ID.

Budiarti, S.W., H. Purwaningsih, Suwarti. 2013. Kontaminasi fungi Aspergillus sp. pada biji jagung di tempat penyimpanan dengan kadar air yang berbeda. hal. 482-487. In Muis, A., M.S. Pabbage, M. Yasin, M. Aqil, Hermanto, S. Pakki (Eds.). Prosiding Seminar Nasional Serealia "Meningkatkan Peran Penelitian Serealia dalam Mendukung Pertanian Bioindustri. Maros 18 Juni 2013.

Cosmas, P., G. Cristopher, K. Charles, K. Friday, M. Ronald, M.Z. Belta. 2012. Tagetes minuta formulation effect Sitophilus zeamais (Weevils) control in stored maize grain. Int. J. Plant Res. 2:65-68.
Dobie, P. 1974. The laboratory assessment of the inherent susceptibility of maize varieties to post harvest infestation by Sitophilus zeamais Motsch. (Coleoptera: Curculionidea) infesting field corn. J. Entomol. Sci. 21:367-375.

Gwinner, J., R Harnish, O. Muck. 1996. Manual on the prevention of post-harvest grain losses. Deutsche Gesellschatt for Techische Zusammenarbeit, Eschborn, Jerman, GE.

Hasnah, M. Rahim, L. Suryanti. 2014. Efikasi serbuk lada hitam dalam mengendalikan hama Sitophilus zeamais pada biji jagung selama penyimpanan. J. Penelitian Universitas Jambi Seri Sains 16:23-32.

Hendrival dan E. Mayasari. 2017. Kerentanan dan kerusakan beras terhadap serangan hama pasca panen Sitophilus zeamais L (Coleoptera: Curculionidae). J. Agro. 4:68-79.

Herlina, L., B. Istiaji. 2013. Respon ketahanan beberapa varietas gandum terhadap hama gudang Sitophilus zeamais (Coleoptera: Dryophthoridae). Bul. Plasma Nutfah 19:89-101.

Keba, T., W. Sori. 2013. Differential resistance of maize varieties to the maize weevil (Sitophilus zeamais Motshusky) (Coleoptera: Curculionidae) under laboratory condition. J. Entomology 10:1-12.

Mas'ud, S., A. Tenrirawe, Masmawati, H.G. Yasin. 2009. Pengujian ketahanan jagung quality protein maize (QPM) terhadap hama kumbang bubuk jagung (Sitophilius zeamais). Prosiding Seminar Nasional Serealia. Maros 29 Juli 2009.

Nayaka, S. Chandra, U. Shankar, C. Arakere, Reddy, Munagala, Niranjana, Siddapura, H.S. Prakas, Setty, Huntrike. 2009. Control of Fusraium verticilloides, cause of ear rot of maize, by Pseudomonas flourescens. Pest Management Science Indian Acad. Sci. 65:769-775. 
Nonci, N., A. Muis. 2015. Biologi, gejala serangan, dan pengendalian hama bubuk jagung Sitophilus zeamais Motschulsky (Coleoptera: Curculionidae). J. Penelitian dan Pengembangan Pertanian 34:61-70.

Pakki, S. 2016. Cemaran mikotoksin, bioekologi patogen Fusarium verticilloides dan upaya pengendaliannya pada tanaman jagung. J. Litbang Pertanian 35:11-16.

Respyan, G., B.T. Rahardjo, L.P. Astuti. 2015. Pengaruh insert dust terhadap mortalitas Sitophilus zeamais Mostchulsky pada biji jagung dalam simpanan. J. HPT 3:31-38.

Siwale, J., K. Mbata, J. McRobert, D. Lungu. 2009. Comparative resistance of improved maize genotypes and landraces to maize weevil. African Crop Sci 17: $1-16$.

Siregar, S. 2013. Statistik Parametric untuk Penelitian Kuantitatif. Jakarta. PT. Bumi Aksara.

Suleiman, R.A., 2015. Evaluation of maize weevils Sitophilus zeamais Mostschusky infestation on seven varieties of maize. J. Stored Products Res. 64: 97102.

Suriani, R.N. Iriany, A.T. Makkulawu. 2016. Analisis sidik lintas karakter morfologi dan komponen hasil jagung hibrida umur genjah. Buletin Penelitian Tanaman Serealia 1:24-31.

Surtikanti. 2004. Kumbang bubuk Sitophilus zeamais Motch. (Coleoptera: Curculionidae) dan strategi pengendaliaanya. J. Litbang Pertanian 23:123-129.
Tefera, T., S. Mugo, P. Likhayo. 2011. Effects of insect population density and storage time on grain damage and weight loss in maize due to the maize weevil Sitophilus zeamais and the larger grain borer Prostephanus truncatus. Afr. J. Agric. Res. 6:22492254.

Tenrirawe, A. 2004. Pengujian ketahanan berbagai varietas/ galur jagung berprotein tinggi terhadap kumbang bubuk jagung Sitophilus zeamais Motschulsky (Coleoptera: Curculionidae). Tesis. Sekolah Pascasarjana. Institut Pertanian Bogor. Bogor.

Tenrirawe, A., J. Tandiabang. 2009. The effect of phenolic acid of several quality protein maizelines (QPM) on the resistance to maize weevil, Sitophilus zeamais Motschulsky (Coleoptera: Curculionidae). p 382386. In Zaidi, P.H., M. Azrai, K. Pixley (Eds.). Proceeding of The Tenth Asian Regional Maize Workshop "Maize for Asia Emerging Trends and Technologies". Makassar 20-23 October 2008.

Tenrirawe, A., M.S. Pabbage dan A. Takdir. 2013. Pengujian ketahanan galur jagung hibrida umur genjah terhadap hama kumbang bubuk Sitophilus zeamais Motshulsky. hal. 472-481. In Muis, A., M.S. Pabbage, M. Yasin, M. Aqil, Hermanto, S. Pakki (Eds.). Prosiding Seminar Nasional Serealia "Meningkatkan Peran Penelitian Serealia dalam Mendukung Pertanian Bioindustri. Maros 18 Juni 2013.

Zainal, A., A. Anwar, S. Ilyas, Sudarsono, Giyanto. 2011. Uji inokulasi dan respon ketahanan 38 genotipe tomat terhadap Clavibacter michiganensis subsp. Michiganensis. J. Agron. Indonesia 39:85-91. 